\title{
Quantum chemistry molecular modelling for mitochondria targeted chemotherapy: Verification of oxidative stress on mitochondria and anticancer medicines
}

\author{
Shozo Yanagida ${ }^{1 *}$, Susumu Yanagisawa ${ }^{2}$ and Nobuyuki Murakami ${ }^{3}$ \\ ${ }^{1} \mathrm{M} 3$ laboratory, Inc, ISIR, Osaka University, Osaka, Japan \\ ${ }^{2}$ Departement of Physics and Earth Sciences, Faculty of Science, University of the Ryukyus, Okinawa, Japan \\ ${ }^{3}$ Holos Matsudo Clinic, Matsudo, Chiba, Japan
}

\begin{abstract}
Background: We understand that most diseases which are accompanied with aging must relate to oxidative stress, i.e. oxidative damage of lipid lamellar bimolecular membranes of mitochondria $(\boldsymbol{m t})$. So-called cancer and tumor are groups of such diseases and are diagnosed on the basis of hard spot touch and cell-deformed invasion image obtained by optical microscope, but molecular-level definition of cancer and tumor cells is unclear. The hard spot and/or the cell invasion will be symptoms relating to metabolic dysfunctions of cells, and hydrogen peroxide-derived hydroxyl radical must induce oxidative degradation of lipid lamellar membranes of $\boldsymbol{m} \boldsymbol{t}$ in the cells. Our goal is to gain insights into reactivity of hydrated HOOH and hydroxyl radicals which produce and exist inevitably in $\boldsymbol{m} \boldsymbol{t}$, and instability of the $\boldsymbol{m} \boldsymbol{t}$ 's lipid bimolecular membrane. The result allows us to propose candidates for anticancer medicines which may have antioxidative effects on sustainable $\boldsymbol{m} \boldsymbol{t}$ 's membranes.

Materials and methods: Quantum chemistry molecular modeling, i.e., density functional theory-based molecular modeling (DFT/MM) can be regarded as theorybased "experiments". DFT/MM can be carried out very quickly using high-end supercomputer-like personal computers. The molecular unit consisting bimolecular membranes is glycerin triester of lauric acid [Gly(n-C $\left.\left.{ }_{11} \mathrm{H}_{23} \mathrm{COO}\right)_{3}\right]$. DFT/MM are applicable to molecular aggregates which are induced by van der Waals (vdW) force (i.e. hydrogen bonding and Coulomb interactions). DFT/MM for structuring of aggregates predicts heat of formation, dipole moment for understanding solubility in water, and volume of CPK model of the aggregates as quantitative structure activity for considering penetration of lipid bimolecular membranes of cells, and the energy structures of aggregates, i.e. surface molecular orbital electron energy structures (almost degenerate highest molecular orbitals $(\mathrm{HOMO}(\mathrm{n}), \mathrm{n}=0 \sim 12)$ and the lowest unoccupied molecular orbital (LUMO) configurations. Their orbital potentials of EHOMO(n), (n), n=0 6, and ELUMO(0), density distribution configuration of surface electron, radical density (spin density) configuration of radical species are evaluated as theory-based "experimental" data for verification and prediction of interacting molecules and radicals. As reported in the preceding papers, we performed DFT/MM using the B3LYP exchange correlation functional and the 6-31G(d) basis set with Spartan'18 (Wavefunction, Inc. Irvine, CA). Prior to the DFT calculation, for electronic properties, the geometries of the molecular aggregates were determined by the molecular mechanics simulation employing the Merck Molecular Force Field (MMFF). Details on the result obtained with DFT/ $\mathrm{MM}$ are described in Figures and Tables of supplementary material.

Results: DFT/MM using glycerin triester of lauric acid [ $\left.\mathrm{Gly}\left(\mathrm{n}-\mathrm{C}_{11} \mathrm{H}_{23} \mathrm{COO}\right)_{3}\right]$ as a lipid model molecule verifies that (1) cooperative van der Waals (vdW) force makes bimolecular lipid-like tetramer, $\left[\mathrm{Gly}\left(\mathrm{n}-\mathrm{C}_{11} \mathrm{H}_{23} \mathrm{COO}\right)_{3}\right]_{4} \cdot(2)$ The lipid-like tetramer undergoes oxidative degradation by vdW aggregation with hydrogen peroxide and degradation reaction with hydroxyl radical. (3) Hydrated $\mathrm{HOOH}$ reacts with superoxide radical anion $\left(\mathrm{O}_{2}{ }^{-}\right)$which always exists in functioning $\boldsymbol{m} \boldsymbol{t}$, giving hydroxyl radical. (4) Oxidative degradation starts from ester sites of $\boldsymbol{m} \boldsymbol{t}$ 's lipid bilayer membranes, leading to degrative swelling of the $\boldsymbol{m} \boldsymbol{t}$ 's membranes. (5) The oxidative degradation causes swelling and/or invasion of the cells containing such degraded $\boldsymbol{m} \boldsymbol{t}$ 's membranes. Well-known anticancer medicines, 5-Fluorouracil, Cisplatin, Oxaliplatin, Vitamin C and thyroid hormone, thyroxine (T4) are verified to suppress oxidation power of HOOH and HO. DFT/MM verifies that the swelling and/or invasion tissues filled with the swollen and dysfunctional $\boldsymbol{m} \boldsymbol{t}$ is an authentic model of cancer.
\end{abstract}

\section{Introduction}

Mitochondria $(\boldsymbol{m t})$ are bean-shaped organelles found in every cell of the body (cell size: $6 \sim 25 \mathrm{~mm}$, cell numbers: $4 \sim 6 \times 10^{13}$ ), being composed by cytoplasmic membranes and lamella. Size and length (diameter: $0.5 \mu \mathrm{m}$, length: $\sim 10 \mu \mathrm{m}$, numbers: $4 \sim 6 \times 10^{16}$ ) are comparable to those of bacteria with different shapes. The $\boldsymbol{m} \boldsymbol{t}$ 's important role is to carry out the way a cell gets energy, i.e. chemical energy for production of ATP for peptide source of cells, and electromagnetic energy (EME) from electron transmitter-like $\boldsymbol{m} \boldsymbol{t}$ in brain and nerve cells. We predict that the highest energetic molecule for ATP and EME in $\boldsymbol{m} \boldsymbol{t}$ is hydrated superoxide anion radical of $\mathrm{O}_{2}-$.
Recent studies on $\boldsymbol{m} \boldsymbol{t}$ revealed that active cells with the most $\boldsymbol{m} \boldsymbol{t}$ are heart (each cell is known to contain $\sim 2000$ pieces of $\boldsymbol{m t}$ ), brain, stomach, intestines, liver, pancreas, kidney and muscle, and that most illness must come from dysfunctions of $\boldsymbol{m t}$-filled cells, i.e. decline of $\boldsymbol{m t}$ as bioenergy source of cells [1-4]. In fact, cancer and tumor often occur on tissues of $\boldsymbol{m} \boldsymbol{t}$-filled cells.

${ }^{\star}$ Correspondence to: Shozo Yanagida, M3 laboratory, Inc, ISIR, Osaka University, Osaka, Japan, E-mail: yanagida@mls.eng.osaka-u.ac.jp

Key words: Density functional theory (DFT), 5-Fluorouracil, Cisplatin, Sorafenib, Vitamin C

Received: February 20, 2020; Accepted: March 12, 2020; Published: March 18, 2020 

medicines

Japan National Cancer Center Research Institute (NCCRI) reported that cancer is a disease associated with aging and environmental risk factors, and that most cancers develop with genomic instability and a number of mutations after middle age $[5,6]$. We understand, however, that while the genomic instability occurs in $\boldsymbol{m} t$, oxidative degradation starts on $\boldsymbol{m} \boldsymbol{t}$ 's lipid bimolecular membranes. It is proposed that the lipid bilayer membranes accumulate hydrogen peroxide $(\mathrm{HOOH})$ with age, and hydroxyl radical (HO) will form in situ from $\mathrm{HOOH}$ and $\mathrm{O}_{2}^{-}$. Particularly, HO will cause dysfunction of $\boldsymbol{m} t$ as bioenergy source of cells.

DFT/MM validates: 1) Equilibrium geometry of hydrated $\mathrm{HOOH}$, $\mathrm{HOOH}\left(\mathrm{H}_{2} \mathrm{O}\right)_{2}$ and their energy structures, 2) The in-situ formation of hydrated hydroxyl radical and its destructive reactivity, 3) Energy structures of lipid bimolecular membranes and stability, 4) Oxidative degradation of lipid membranes, and 5) Antioxidative effects of anticancer medicines.

\section{Verification of equilibrium geometry and energy structure of $\mathrm{HOOH}\left(\mathrm{H}_{2} \mathrm{O}\right)_{2}$}

In the preceding papers, DFT/MM verified that superoxide radical anion $\left(\mathrm{O}_{2}{ }^{-}\right)$is produced from $\mathrm{D}$-glucose and triplet oxygen ${ }^{3} \mathrm{O}_{2}$, and $\mathrm{O}_{2}{ }^{-}$ works as energy source for $\boldsymbol{m} \boldsymbol{t}$ metabolism. However, $\mathrm{O}_{2}{ }^{--}$undergoes a side reaction, giving hydrogen peroxide $(\mathrm{HOOH})[1,2]$. We now verify on the basis of DFT/MM (Figure 1) that bicyclic hydrated $\mathrm{HOOH}$, and monocyclic hydrated $\mathrm{HOOH}$ will form in water phase of $\boldsymbol{m} \boldsymbol{t}$ with heat of formation of respective $\Delta \mathrm{E}=-23.8$ and $\Delta \mathrm{E}=-25.9 \mathrm{kcal} / \mathrm{mol}$. In both cases, the lowest electron accepting molecular orbital configuration (LUMO configuration; mesh presentation) locates on the $\mathrm{HOOH}$ site, verifying that preferential reductive electron transfer is likely to occur to $\mathrm{HOOH}$, generating $\mathrm{HO}$ (Figure 2). In addition, we find that $\mathrm{HOOH}\left(\mathrm{H}_{2} \mathrm{O}\right)_{2}$ may aggregate with D-glucose and with $\mathrm{O}_{2}{ }^{-}$(Figure 1). Their electron energy potential verifies that reductive electron transfer will result in giving HO preferentially and instantly.

\section{Verification of in-situ formation of hydrated HO and destructive reactivity}

Figure 2 shows that monocyclic hydrated hydrogen peroxide, $\mathrm{HOOH}\left(\mathrm{H}_{2} \mathrm{O}\right)_{2}$ undergoes one electron transfer reduction from superoxide radical anion $\left(\mathrm{O}_{2}^{-}\right)$, and removable of hydroxide anion (HO ) leads to exothermic formation of hydrated hydroxyl radical [ $\mathrm{HO}$ $\left.\left(\mathrm{H}_{2} \mathrm{O}\right)_{2}\right]$. Formation of intermediary radical anion, $\left.\left[\mathrm{HOOH}\left(\mathrm{H}_{2} \mathrm{O}\right)_{2}\right]^{-}\right]$ validates the bond fission between $\mathrm{O}-\mathrm{O}$ bond of $\mathrm{HOOH}$ by one-electron transfer reduction. In general, aging of the creature accompanies lack of aerobic exercise, and the lack of aerobic exercise accelerates a side reaction with $\mathrm{O}_{2}^{--}$, i.e. in-situ production of harmful $\mathrm{HO}$ from $\mathrm{O}_{2}{ }^{--}$and $\mathrm{HOOH}$.

DFT/MM also verifies that radical (spin) density of $\left[\mathrm{HO} \cdot\left(\mathrm{H}_{2} \mathrm{O}\right)_{2}\right]$ locates on both of $\mathrm{HO}$ and $\mathrm{H}_{2} \mathrm{O}$, indicating delocalization of spin. However, electron accepting potential, i.e. spin oxidation potential EbLUMO (spin) is verified to be low $-3.63 \mathrm{eV}$, and electron donating potential, i.e. SOMO potential $\mathrm{EbHOMO(SOMO)} \mathrm{to} \mathrm{be} \mathrm{also} \mathrm{low}-7.95$ $\mathrm{eV}$. In addition, electron accepting potential of bare $\mathrm{HO}$ is verified to be $-4.16 \mathrm{eV}$. Hydrated $\mathrm{HO}$ will be in equilibrium with the bare $\mathrm{HO}$, keeping high reactivity of oxidative hydrogen abstraction. The hydrogen abstractions are often observed as intermediates in DFT/MM-based equilibrium geometry determination.

\section{Verification of energy structures of lipid bimolecular membranes and stability}

In order to demonstrate energy structures of lipid lamellar membranes, self-aggregation of glycerin triester of lauric acid, Gly(n$\left.\mathrm{C}_{11} \mathrm{H}_{23} \mathrm{COO}\right)_{3}$ is examined. The self-aggregation is molecular-modeled by single point energy (SPE) determination for molecular mechanicsbased structure (Figure S1, Table S1). As the energy structures, heat of formation for self-organization and distribution of HOMO's distribution for SPE-based determined aggregate structures are shown.

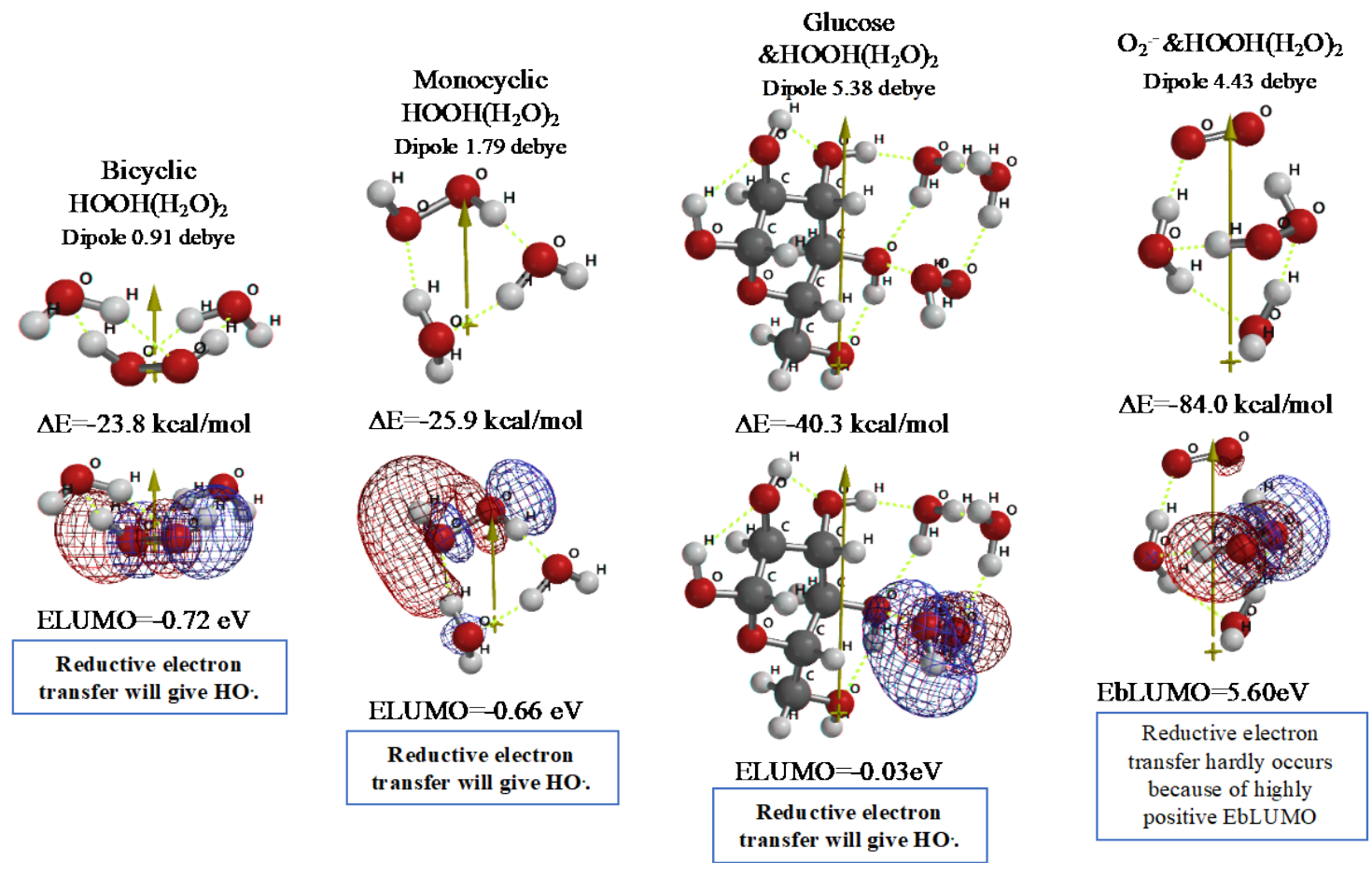

Figure 1. Verification of equilibrium geometries of $\mathrm{HOOH}$-aggregated species and their energy structures 


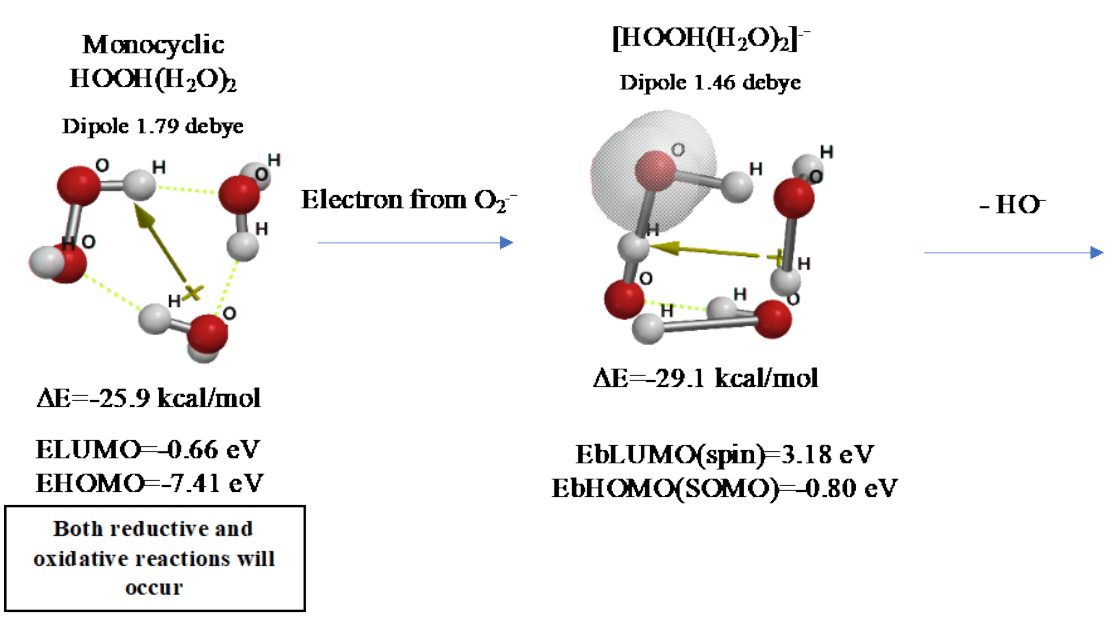

Figure 2. Verification of hydroxyl radical (HO) formation from $\mathrm{HOOH}$ and $\mathrm{O}_{2}$
The SPE-based aggregates have compact structures when compared to equilibrium geometry (EQG)-based determined structures, implying that the SPE-determined structures are appropriate for lipid stacked state bimolecular membranes. Previously, we reported a similar verification for the three-dimension structure of crystalline benzene [6].

The parallel dimer of (b) $\left[\mathrm{Gly}\left(\mathrm{n}-\mathrm{C}_{11} \mathrm{H}_{23} \mathrm{COO}\right)_{3}\right]_{2}$, is verified to form with heat of formation of $\Delta \mathrm{E}=-1.01 \mathrm{kcal} / \mathrm{mol}$ (Table S1), and the bilayer-type dimer of (c) $\left[\mathrm{Gly}\left(\mathrm{n}-\mathrm{C}_{11} \mathrm{H}_{23} \mathrm{COO}\right)_{3}\right]_{2}$, with $\Delta \mathrm{E}=+0.37$ (A in Figure 3). Interestingly, the tetramer from the bilayer-type dimer, i.e., the lamellar-type tetramer of $(\mathrm{g})\left[\mathrm{Gly}\left(\mathrm{n}-\mathrm{C}_{11} \mathrm{H}_{23} \mathrm{COO}\right)_{3}\right]_{4}$ is verified to form with heat of formation of $\Delta \mathrm{E}=-24,670 \mathrm{kcal} / \mathrm{mol}$ ( $\mathrm{B}$ in Figure 3). On the other hand, the heats of formation of $\Delta E=-1.01 \mathrm{kcal} / \mathrm{mol}$ (SPE) and $\Delta \mathrm{E}=-2.77 \mathrm{kcal} / \mathrm{mol}$ (EQG) are verified for the parallel dimer, and $\Delta \mathrm{E}=-0.006 \mathrm{kcal} / \mathrm{mol}(\mathrm{SPE})$ and $\Delta \mathrm{E}=-24.6 \mathrm{kcal} / \mathrm{mol}$ (EQG) for the parallel trimer combined (see Table S1). Given the heat of formation of $\Delta \mathrm{E}=+0.37 \mathrm{kcal} / \mathrm{mol}(\mathrm{SPE})$ and $\Delta \mathrm{E}=-0.628 \mathrm{kcal} / \mathrm{mol}$ (EQG) for the bilayer-type dimer, remarkable and cooperative vdW-force stabilization must play a decisive role in construction of the lamellar-type tetramer of [Gly ( $\left.\left.\mathrm{n}-\mathrm{C}_{11} \mathrm{H}_{23} \mathrm{COO}\right)_{3}\right]_{4}$. In other words, lipid lamellar membranes are stabilized by taking both parallel and bilayer type aggregation of lipid triglyceride unit.

Taking into account the cooperative vdW force in the lamellartype tetramer, a three-dimension membrane model is speculated by arranging nine units of the lamellar-type tetramer. The vdW forces via surface electron density and HOMO distribution are also depicted to predict the stability and reactivity of lipid lamellar membranes $(\mathrm{C}$ in Figure 3).

The surface energy structure, distribution of configurations of $\mathrm{HOMO}(0) \sim(11)$ is worth noting for structural stability. The HOMO distribution predicts that alkyl chain sites are stable enough for oxidation but surface ester sites are not, predicting that lipid bilayer membranes aggregate with hydrated $\mathrm{HOOH}$ and $\mathrm{HO}$ especially at polar ester sites of lamellar membranes. In other words, the lipid bilayer membranes are fairly stable in biological redox reaction systems like cells and $\boldsymbol{m t}$. The surface ester site undergoes firstly oxidative degradation, and the swollen lamellar membranes will have space at alkyl chain sites, undergo the attack by hydroxyl radical, and the lamellar membrane structures will be destroyed oxidatively.

\section{Verification of oxidative degradation of lipid membranes}

Energy structures of glycerin triester (a) Gly $\left(n-\mathrm{C}_{11} \mathrm{H}_{23} \mathrm{COO}\right)_{3}(\mathrm{SPE})$, the parallel trimer (e) $\left[\mathrm{Gly}\left(\mathrm{n}-\mathrm{C}_{11} \mathrm{H}_{23} \mathrm{COO}\right)_{3}\right]_{3}(\mathrm{SPE})$, and the bilayertype tetramer $(\mathrm{g})\left[\mathrm{Gly}\left(\mathrm{n}-\mathrm{C}_{11} \mathrm{H}_{23} \mathrm{COO}\right)_{3}\right]_{4}(\mathrm{SPE})$ are shown in Figure S2, S3, and Figure 4. The HOMO configurations distribute at ester sites and alkyl chain sites, indicating that $\mathrm{HOOH}$ and $\mathrm{HO}$ react not only at ester sites but also at alkyl chain sites of the triglyceride and their aggregates. Aggregation of hydrated $\mathrm{HOOH}, \mathrm{HOOH}\left(\mathrm{H}_{2} \mathrm{O}\right)_{2}(\mathrm{cyclic})$ at alkyl chain sites and at ester sites are molecular modeled (EQG) for heat of formation $(\Delta \mathrm{E})$, configurations and energy potential of HOMO and LUMO and volume of the CPK model (Figure 4, Table S2). As for the aggregation at alkyl chain sites, $\mathrm{HOOH}$ molecule still have potential to be reduced to $\mathrm{HO}$ by attack of $\mathrm{O}_{2}{ }^{-}$since the LUMO configuration locates also at the $\mathrm{HOOH}$ molecule on the alkyl chain site.

The heat of formation, $(\Delta \mathrm{E}=-30.3 \mathrm{kcal} / \mathrm{mol}, \Delta \mathrm{E}=-38.4 \mathrm{kcal} / \mathrm{mol})$ and the energy structure change verify that the aggregation occurs exothermically and $\mathrm{HOOH}$ molecules are more stabilized by vdW force at the ester sites. Interestingly, LUMO is verified not to locate at the $\mathrm{HOOH}$ molecule which is aggregated on ester sites, indicating that $\mathrm{HOOH}$ molecules can be accumulated at ester sites of lamellar membranes.

As for the aggregation of $\mathrm{HO} \cdot\left(\mathrm{H}_{2} \mathrm{O}\right)_{2}$ with $\mathrm{Gly}\left(\mathrm{n}-\mathrm{C}_{11} \mathrm{H}_{23} \mathrm{COO}\right)_{3}$ (Figure 5), hydrogen abstraction reaction occurs at alkyl chain sites. It is worth noting that the ester-site aggregation with $\mathrm{HO} \cdot\left(\mathrm{H}_{2} \mathrm{O}\right)_{2}$ accompanies large conformation change. Larger exothermic heat of formation $(\Delta \mathrm{E}=-37.1 \mathrm{kcal} / \mathrm{mol}, \Delta \mathrm{E}=-34.2 \mathrm{kcal} / \mathrm{mol})$ and 3-dimension molecular change validate vivid oxidative degradation of lipid molecules, especially when $\mathrm{HOOH}$ molecules on ester sites are converted into $\mathrm{HO}$ in biological redox systems, i.e. in $\boldsymbol{m t}$. Oxidative morphological change accelerates oxidation of alkyl chain sites of collapsing membranes.

\section{Verification of antioxidative effects of anticancer medicines}

Cancer and tumor cells induce dysfunction of metabolism in organs of body, and any dysfunction of cells results from initial degradation of powerhouse of cells, i.e. oxidative damage of lipid lamellar membranes of $\boldsymbol{m} t$. From perspective of chemotherapy of cancer and tumor, oxidative collapse of lipid lamellar membranes will be suppressed by anticancer medicines if their molecular size is small enough to reach vicinity of $\boldsymbol{m} \boldsymbol{t}$ 

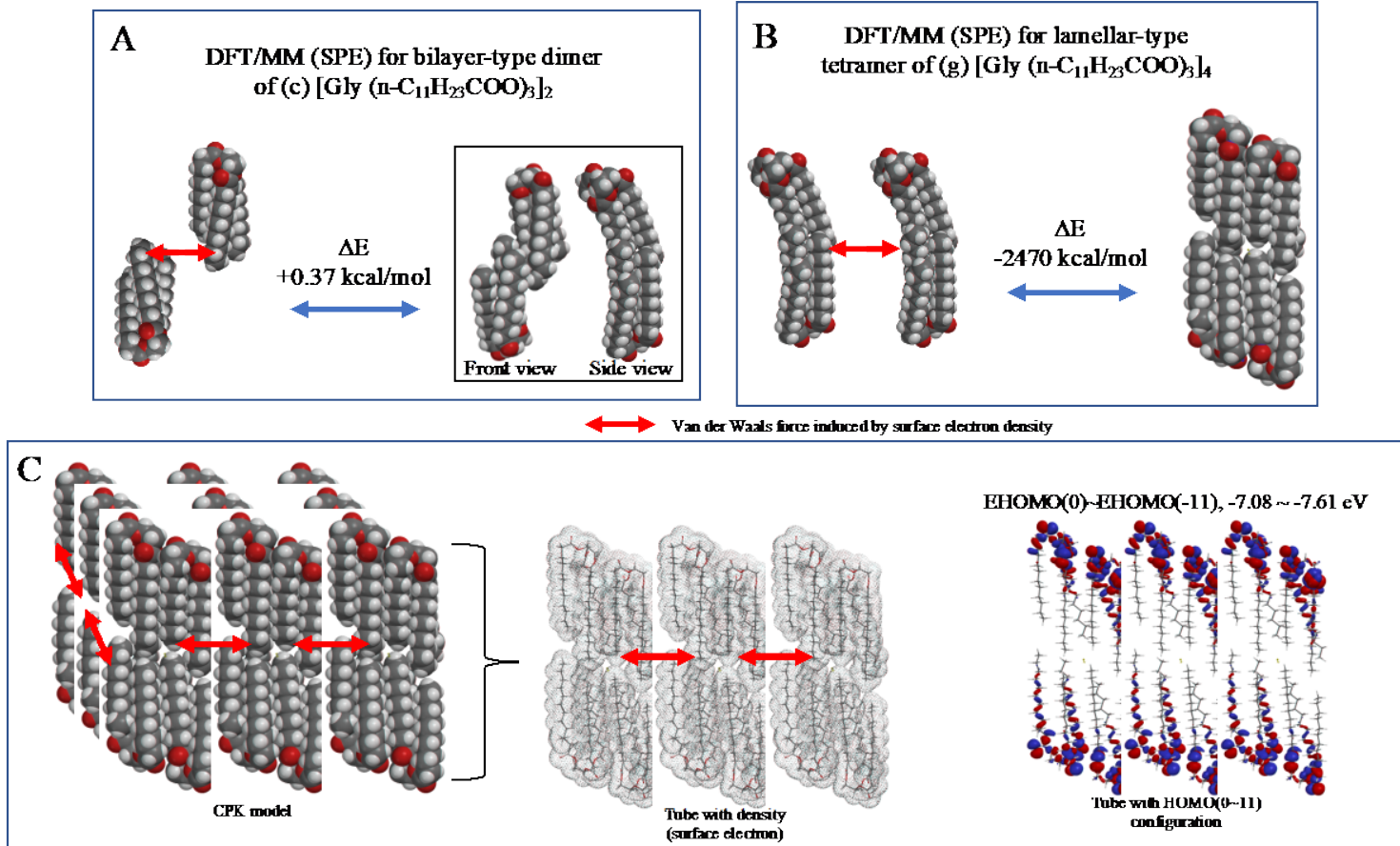

Figure 3. Lamellar-type lipid membrane model predicted by vdW force-induced aggregates composed of DFT/MM(SPE)-based lamellar-type tetramer of $(\mathrm{g})\left[\mathrm{Gly}\left(\mathrm{n} \mathrm{C}_{11} \mathrm{H}_{23} \mathrm{COO}\right)_{3}\right]_{4}(\mathrm{SPE})$

\section{$\mathrm{Gly}\left(\mathrm{n}-\mathrm{C}_{11} \mathrm{H}_{23} \mathrm{COO}\right)_{3}$ \\ CPK Volume $\left(\AA^{3}\right) 769.45$}
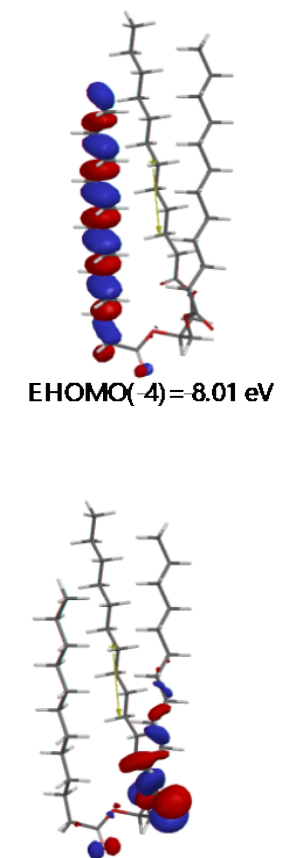

EHOMO $=7.25 \mathrm{eV}$

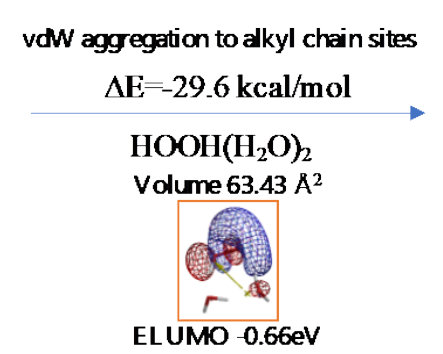

ELUMO $-0.66 \mathrm{eV}$

\section{$\mathrm{HOOH}\left(\mathrm{H}_{2} \mathrm{O}\right)_{2} \& \mathrm{Gly}\left(\mathrm{n}-\mathrm{C}_{11} \mathrm{H}_{23} \mathrm{COO}\right)_{3}$ CPK Volume $\left(\AA^{3}\right) 83274$ $\Delta$ volume $=61.1 \AA^{3}$}

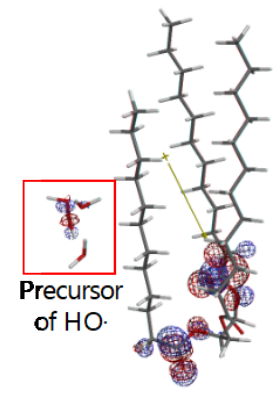

ELUMO $=-0.30 \mathrm{eV}$

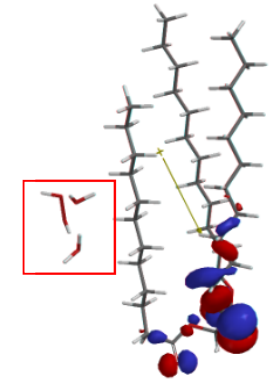

EHOMO $=-7.18 \mathrm{eV}$

CPK Volume $\left(\AA^{3}\right) 830.55$ $\Delta$ volume $=63.11 \AA^{3}$

$\mathrm{vd} W$ aggregation to ester sites

$\Delta \mathrm{E}=-38.4 \mathrm{kcal} / \mathrm{mol} \longrightarrow$

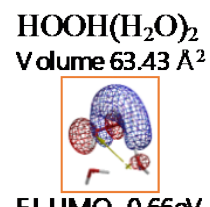

ELUMO $-0.66 \mathrm{eV}$

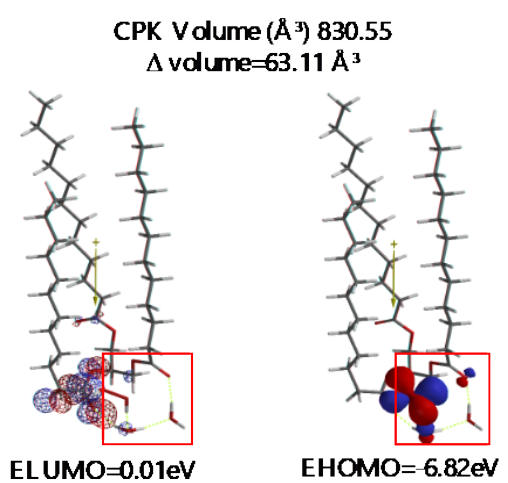

Figure 4. Equilibrium geometry and energy structure of van der Waals aggregate of $\left.\mathrm{HOOH}_{(} \mathrm{H}_{2} \mathrm{O}\right)_{2}$ on lipid membrane unit model of Gly(n$\left.\mathrm{C}_{11} \mathrm{H}_{23} \mathrm{COO}\right)_{3}$ 


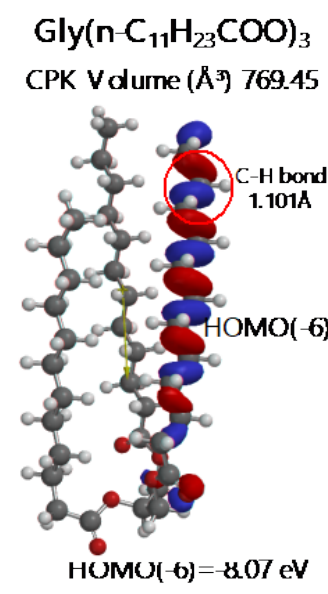

vdW aggregation to alkyl chain sites

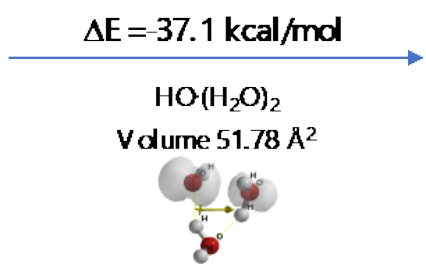

E(b)L UMO $-3.63 \mathrm{eV}$

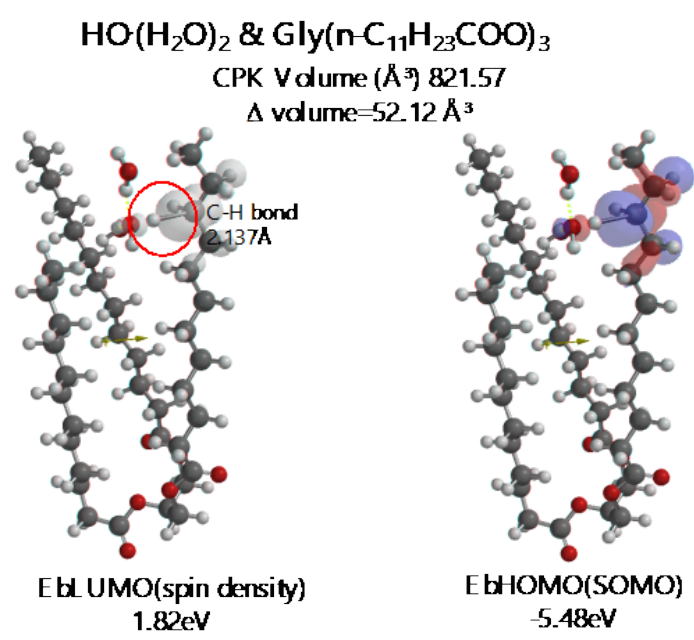

CPK Volurne $\left(\AA^{3}\right) \mathbf{8 1 9 . 2 4}$ $\triangle$ volume $=48.79 \AA^{3}$

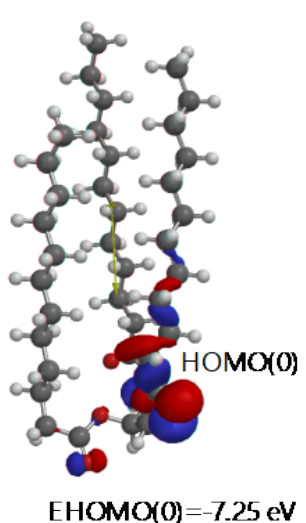

$\mathrm{EHOMO}(0)=-7.25 \mathrm{eV}$

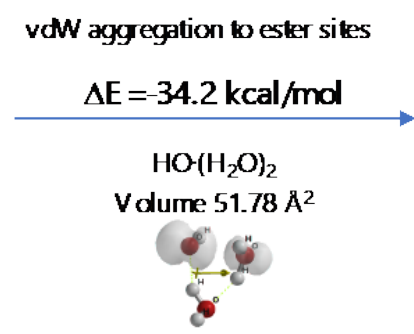

E(b)L UMO -3.63 eV

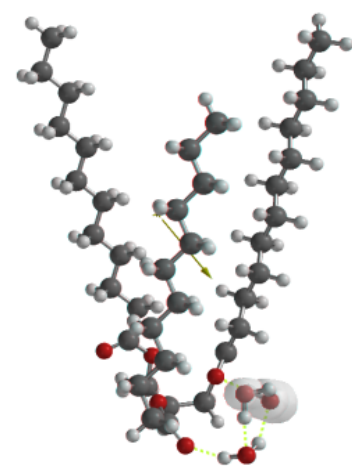

EbL UMO(spin density)

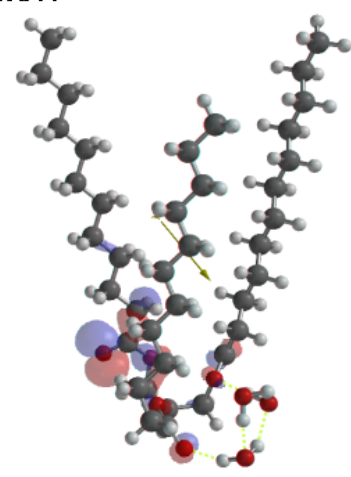

EbHOMO(SOMO)

$-7.51 \mathrm{eV}$

Figure 5. Equilibrium geometry and energy structure of van der Waals aggregate of $\mathrm{HO}\left(\mathrm{H}_{2} \mathrm{O}\right)_{2}$ on lipid membrane model of $\mathrm{Gly}\left(\mathrm{n}-\mathrm{C}_{11} \mathrm{H}_{23} \mathrm{COO}\right)_{3}$

through lipid lamellar membranes of cells. DFT/MM of the smallest anticancer medicine, Flurouracil (5-Fluorouracil) [8] is evaluated to clarify difference in antioxidative effect from that of uracil in the nucleic acid of RNA.

Both 5-Fluorouracil and uracil have three different ring structures due to the tautomerism; 1. amid, hydroxyl, 2. amid, amid, 3. hydroxyl, hydroxyl in the pyrimidine ring structure. Three equilibrium geometry structures and energy structures of the aggregates with $\mathrm{HOOH}\left(\mathrm{H}_{2} \mathrm{O}\right)_{2}$, and with $\mathrm{HO} \cdot\left(\mathrm{H}_{2} \mathrm{O}\right)_{2}$ validate the vdW aggregation (Figure 6 and Figure S4).

Interestingly, each of the aggregations with $\mathrm{HO} \cdot\left(\mathrm{H}_{2} \mathrm{O}\right)_{2}$ provides transition states to oxidation products, which is formed by C-F or O-H bond fission (Figure S5, S6, S7). It is noteworthy that although spin density potential (EbLUMO) of each intermediate ranges from $-4.84 \sim$ $-2.36 \mathrm{eV}$, the spin density is all delocalized on pyrimidine rings, not on $\mathrm{HO}$. The large negative heat of formation of $\Delta \mathrm{E}=-62 \sim-68 \mathrm{kcal} / \mathrm{mol}$ also verifies antioxidative effect of 5-Fluorouracil.

The same verification is true for uracil isomers (Figure S4). It is worth noting, however, that difference in antioxidative effects comes from different exothermic heat of formation. 5-Fluorouracil reacts more exothermically with $\mathrm{HOOH}$ and $\mathrm{HO}$ than uracil. DFT/MM results verify that 5-Fluorouracil is able to eliminate $\mathrm{HOOH}$ and $\mathrm{HO}$. from $\boldsymbol{m} \boldsymbol{t}$ vicinity, i.e. 5-Fluorouracil is more effective antioxidant than uracil (Table 1).

As shown in Figure 7 and Table 1, platinum complexes, Cisplatin and Oxaliplatin [8], and chlorine atom-containing Sorafenib all aggregate with $\mathrm{HOOH}\left(\mathrm{H}_{2} \mathrm{O}\right)_{2}$, and react with $\mathrm{HO} \cdot\left(\mathrm{H}_{2} \mathrm{O}\right)_{2}$. They all proceed highly exothermic, thus implying effective antioxidative effects. It is noteworthy that platinum metal has an interesting capability of decreasing oxidative reactivity of $\mathrm{HO}$. Both aggregates with $\mathrm{HO} \cdot\left(\mathrm{H}_{2} \mathrm{O}\right)_{2}$ have spin density which is delocalized onto the platinum (II) atom with spin density potential, EbLUMO(spin) $=-3.74$ and $-3.30 \mathrm{eV}$, being much higher than that of bare HO (EbLUMO=-4.18 eV).

Aggregation of Sorafenib with $\mathrm{HOOH}\left(\mathrm{H}_{2} \mathrm{O}\right)_{2}$ and its degradative reaction with $\mathrm{HO} \cdot\left(\mathrm{H}_{2} \mathrm{O}\right)_{2}$ proceeds exothermically, and thus results in large heat of formation. Effective delocalization of spin density with spin potential $($ EbLUMO $($ spin $)=-4.13 \mathrm{eV})$ verifies antioxidative effects as an anticancer medicine. The heat of formation of the aggregation and reactions of Sorafenib is summarized together with those of Vitamin $\mathrm{C}$, and thyroxine (T4) of thyroid hormone in Table 1 and Figure S11. To our knowledge, Vitamin C, and thyroxine (T4) are also effective for cancer therapy [9]. 


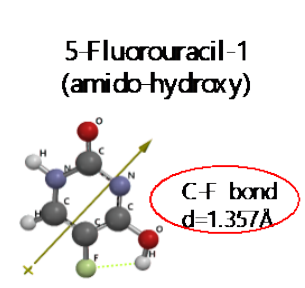

CPK Volume ( $A$ 3) 105.42
$\mathrm{HOOH}\left(\mathrm{H}_{2} \mathrm{O}\right)_{2} \& 5$-Fulorouracil-1

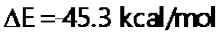

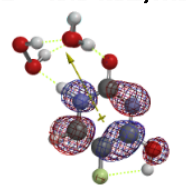

$E L U M O=-1.85 \mathrm{eV}$

$\mathrm{HO}\left(\mathrm{H}_{2} \mathrm{O}\right)_{2} \& 5$-Fulorouracil-1

$\Delta \mathrm{E}=62.3 \mathrm{kcal} / \mathrm{mol}$

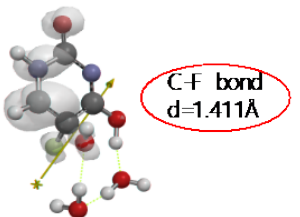

EbLUMO (spin density) $-270 \mathrm{eV}$

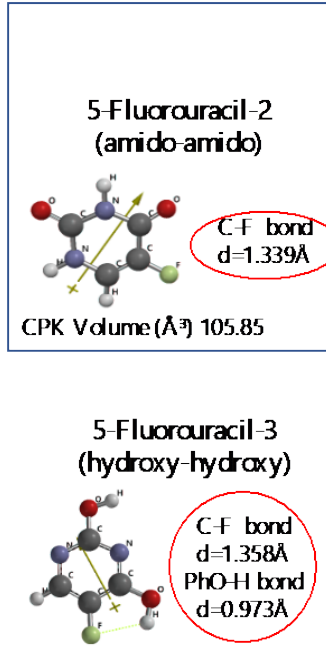

CPK Volume $\left(\AA^{\sharp}\right) 104.83$

$\mathrm{HOOH}\left(\mathrm{H}_{2} \mathrm{O}\right)_{2} \& 5$-Fulorouracil-2

$$
\Delta \mathrm{E}=-33.2 \mathrm{kcal} / \mathrm{mol}
$$

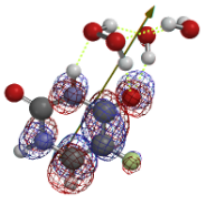

$E L U M O=-2.03 \mathrm{eV}$

$\mathrm{HOOH}\left(\mathrm{H}_{2} \mathrm{O}\right)_{2} \& 5$-Fulorouracil-3

$\Delta \mathrm{E}=-41.0 \mathrm{kcal} / \mathrm{mol}$

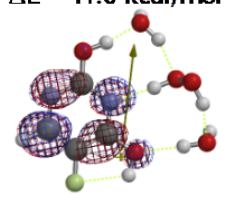

$E L U M O=-1.19 \mathrm{eV}$
$\mathrm{HO}\left(\mathrm{H}_{2} \mathrm{O}\right)_{2} \& 5$-Fularouracil-2

$$
\Delta E=-62.6 \mathrm{kcal} / \mathrm{mol}
$$

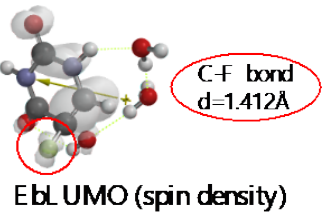

EbL UMO (spin density) $2.36 \mathrm{eV}$

$\mathrm{HO}\left(\mathrm{H}_{2} \mathrm{O}\right)_{2} \& 5$-Fuldrouracil-2

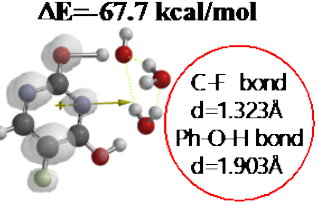

EbLUMO (spin density) $4.84 \mathrm{eV}$

Figure 6. Equilibrium geometry and energy structures of van der Waals aggregation of 5-Fuluoruracil with $\mathrm{HOOH}\left(\mathrm{H}_{2} \mathrm{O}\right)_{2}$ and $\mathrm{HO} \cdot\left(\mathrm{H}_{2} \mathrm{O}\right)_{2}$

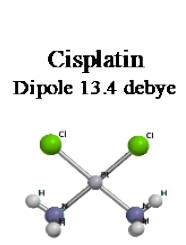

CPK Volume $\left(\AA^{3}\right) 96.02$

\section{$\mathrm{HOOH}\left(\mathrm{H}_{2} \mathrm{O}\right)_{2}$ \&Cisplatin}

$\Delta \mathrm{E}=-46.9 \mathrm{kcal} / \mathrm{mol}$
Dipole $12.60 \mathrm{debye}$

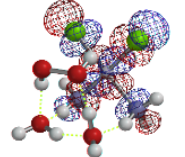

ELUMO=-1.44 eV

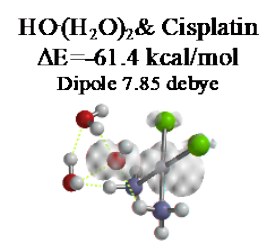

EbLUMO (spin), $-3.74 \mathrm{eV}$ ЕаHOMO (SOMO), $-6.76 \mathrm{eV}$

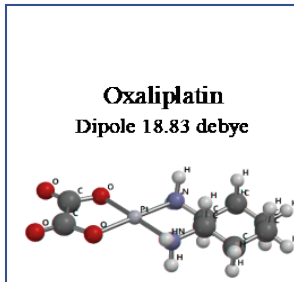

CPK Volume $\left(\AA^{3}\right) 205.37$

$\mathrm{HOOH}\left(\mathrm{H}_{2} \mathrm{O}\right)_{2}$ \&Oxaliplatin

$\mathrm{HO}\left(\mathrm{H}_{2} \mathrm{O}\right)_{2}$ \&Oxaliplatin

$\Lambda \mathrm{E}=-65.1 \mathrm{kcal} / \mathrm{mol}$

$\Delta \mathrm{E}=-50.0 \mathrm{kcal} / \mathrm{mol}$

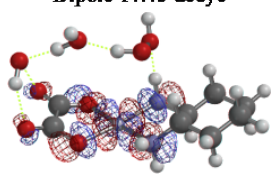

ELUMO $=0.79 \mathrm{eV}$

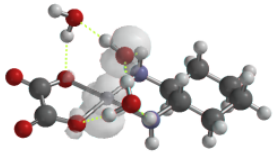

EbLUMO (spin), $-330 \mathrm{eV}$ ЕаHOMO (SOMO)-6.35 eV

$\mathrm{HO}\left(\mathrm{H}_{2} \mathrm{O}\right)_{2}$ \&Sorafenib $\Lambda \mathrm{E}=-59.3 \mathrm{kcal} / \mathrm{mo}$

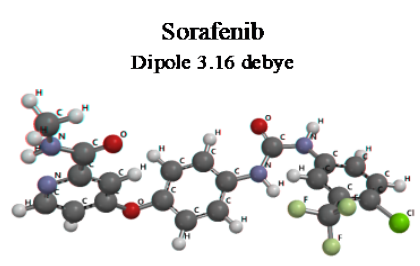

CPK Volume $\left(\AA^{3}\right) 411.92$

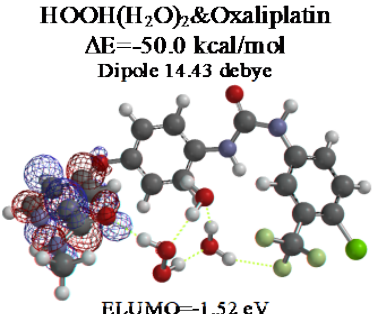

ELUMO- $-1.52 \mathrm{eV}$

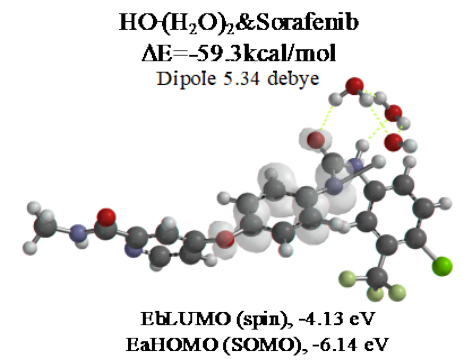

Figure 7. Equilibrium geometry and energy structures of vdW aggregates of cisplatin, oxaliplatin and Sorafenib with $\mathrm{HOOH}\left(\mathrm{H}_{2} \mathrm{O}\right)_{2}$ and $\mathrm{HO} \cdot\left(\mathrm{H}_{2} \mathrm{O}\right)_{2}$ 
Yanagida S (2020) Quantum chemistry molecular modelling for mitochondria targeted chemotherapy: Verification of oxidative stress on mitochondria and anticancer medicines

Table 1. Comparison for antioxidant effects of antitumor medicines and nutrients in view of heat of formation of aggregation with $\mathrm{HOOH}\left(\mathrm{H}_{2} \mathrm{O}\right)_{2}$ and $\mathrm{HO}\left(\mathrm{H}_{2} \mathrm{O}\right)_{2}$

\begin{tabular}{|c|c|c|c|c|}
\hline $\begin{array}{l}\text { Antitumor medicines and } \\
\text { netrients for mitochondria } \\
\text { targeting chemotherapy }\end{array}$ & $\begin{array}{c}\text { CPK volume } \\
\left(\AA^{3}\right)\end{array}$ & $\begin{array}{c}\text { Heat of formation for van der } \\
\text { Waals aggregation with } \mathrm{HOOH} \\
\left(\mathrm{H}_{2} \mathrm{O}\right)_{2} \\
\Delta \mathrm{E}(\mathrm{kcal} / \mathrm{mol})\end{array}$ & $\begin{array}{c}\text { Heat of formation for van der } \\
\text { Waals aggregation with } \\
\mathrm{HO}^{\cdot}\left(\mathrm{H}_{2} \mathrm{O}\right)_{2} \\
\Delta \mathrm{E}(\mathrm{kcal} / \mathrm{mol})\end{array}$ & $\begin{array}{c}\text { Total of heat of formation } \\
\text { as a measure of antioxidant effect } \\
\Delta E(\mathrm{kcal} / \mathrm{mol})\end{array}$ \\
\hline $\begin{array}{l}\text { 5-Fluorouracil (amid, hydroxy) } \\
\text { Uracil-1(amid hydroxy) }\end{array}$ & $\begin{array}{l}105.42 \\
100.83\end{array}$ & $\begin{array}{l}-45.3 \\
-44.5\end{array}$ & $\begin{array}{l}-55.7 \\
-46.3\end{array}$ & $\begin{array}{l}-101 \\
-90.7\end{array}$ \\
\hline $\begin{array}{l}\text { 5-Fluorouracil (amid, amid) } \\
\text { Uracil-2 (amid amid) }\end{array}$ & $\begin{array}{l}105.85 \\
101.17\end{array}$ & $\begin{array}{l}-33.2 \\
-41.9\end{array}$ & $\begin{array}{l}-62.6 \\
-37.4\end{array}$ & $\begin{array}{l}-95.8 \\
-79.7\end{array}$ \\
\hline $\begin{array}{l}\text { 5-Fluorouracil (hydroxy hydroxy) } \\
\text { Uracil-3 (hydroxy hydroxy) }\end{array}$ & $\begin{array}{l}104.83 \\
100.23\end{array}$ & $\begin{array}{l}-41.0 \\
-42.7\end{array}$ & $\begin{array}{l}-67.7 \\
-33.5\end{array}$ & $\begin{array}{l}-109 \\
-76.3\end{array}$ \\
\hline Cisplatin & 96.02 & -46.9 & -61.4 & -108 \\
\hline Oxaliplatin & 205.37 & -50.0 & -65.1 & -115 \\
\hline Sorafenib & 411.92 & -43.0 & -59.3 & -102 \\
\hline Ascorbic acid (Vitamin C) & 149.81 & -37.3 & -77.8 & -115 \\
\hline Thyroxine (T4) & 373.77 & -41.1 & -40.3 & -81.4 \\
\hline $\begin{array}{c}\mathrm{Gly}\left(\mathrm{n}-\mathrm{C}_{11} \mathrm{H}_{23} \mathrm{COO}\right)_{3}(\mathrm{EQG}) \text { at alkyl } \\
\text { sites }\end{array}$ & 769.45 & $-29.6^{*}$ & -37.1 & -66.7 \\
\hline $\begin{array}{c}\mathrm{Gly}\left(\mathrm{n}-\mathrm{C}_{11} \mathrm{H}_{23} \mathrm{COO}\right)_{3}(\mathrm{EQG}) \text { at ester } \\
\text { sites }\end{array}$ & 769.45 & -38.4 & -34.2 & -72.6 \\
\hline D-Glucose & 157.39 & $-40.7 *$ & -57.3 & -98.1 \\
\hline
\end{tabular}

\section{Conclusion}

As for $\boldsymbol{m} \boldsymbol{t}$-targeted cancer therapy, DFT/MM verifies importance of protection of oxidative degradation of lipid bimolecular lamellar membranes of $\boldsymbol{m} \boldsymbol{t}$. As a measure of effectiveness of anticancer medicines, we propose DFT/MM-based heat of formation for aggregations with $\mathrm{HOOH}\left(\mathrm{H}_{2} \mathrm{O}\right)_{2}$ and with $\mathrm{HO}^{\circ}\left(\mathrm{H}_{2} \mathrm{O}\right)_{2}$. Table 1 summarizes them with total heat of formation and $\mathrm{CPK}$ volume of medicines. Effective anticancer medicines must have excellent antioxidative effects on lipid bilayer membranes of $\boldsymbol{m} \boldsymbol{t}$ and the size must be smaller than the lipid size. Otherwise the anticancer medicines cannot go through lipid lamellar membranes of cells and $\boldsymbol{m} \boldsymbol{t}$. Based on the perspective on cancer and tumor syndrome and pharmacological antioxidative effects, we propose that so-called cancer tissues, i.e. swelling and/or invasion tissues must be filled with $\boldsymbol{m} \boldsymbol{t}$ where lipid bimolecular membranes are oxidatively damaged by $\mathrm{HOOH}$-derived hydroxyl radical (HO*). Further DFT/ $\mathrm{MM}$ is in progress to validate and predict side-effect free $\boldsymbol{m} \boldsymbol{t}$-targeted therapy.

\section{References}

1. Yanagida S, Osabe K, Nagai T, Murakami N (2019) Quantum chemistry molecular modeling for longevity: Importance of antioxidative effects in mitochondria as battery of cells. Integr Mol Med 6: 1-10.

2. Yanagida S, Kaname A, Murakami N (2019) Quantum chemistry-based verification of antioxidative action of iodide in mitochondria. Integr Mol Med 6: 1-6.

3. sciencepointmnj.wordpress.com/2016/16/science-point-biology-cell-mitochondria-bymanoj-k-sonkaria/

4. https://www.ncc.go.jp/en/ri/division/carcinogenesis_and_prevention/environmental carcinogenesis/index.html.

5. Valavanidis A, Vlachogianni T, Fiotakis C (2009) There is experimental evidence that oxidative damage permanently occurs to DNA. J Environ Sci Health C 27: 120-139.

6. Yanagida S, Yanagisawa S, Yanagida M, Segawa H (2018) Validity of density-functionaltheory-based molecular modeling for $\mathrm{UV} /$ visible spectroscopy and rationale of panchromatic $\mathrm{PbI}_{6}{ }^{4}\left(\mathrm{MeNH}_{3}{ }^{+}\right)_{4}$-structured molecular solar cells. Jpn J Appl Phys 57: 121602.

7. Information from Wikipedia.

8. Kidani Y, Inagaki K, Iigo M, Hoshi A, Kuretani K (1978) Antitumor activity of -diaminocyclohexaneplatinum complexes against Sarcoma-180 ascites form. $J$ Med Chem 21: 1315-1318.

9. https://pi.oregonstate.edu/mic/minerals/iodine

Copyright: (C2020 Yanagida S. This is an open-access article distributed under the terms of the Creative Commons Attribution License, which permits unrestricted use, distribution, and reproduction in any medium, provided the original author and source are credited. 